\title{
Fossil assemblages and biostratigraphy of metamorphic rocks of the Nevado- Filábride Complex from the Águilas tectonic arc (SE Spain)
}

\author{
Casto LABORDA-LÓPEZ ${ }^{*}$, Julio AGUIRRE ${ }^{2}$, Stephen K. DONOVAN', Pilar NAVAS- \\ $P A R E J O^{4} \&$ Sergio RODRÍGUEZ
}

\footnotetext{
${ }^{1}$ Departamento de Geología, Universidad de Jaén, Escuela Politécnica Superior de Linares, C/ Alfonso X El Sabio, no 28 , edificio A, buzón 8, CP 23700, Linares, Spain; claborda@ujaen.es

${ }^{2}$ Departamento de Estratigrafía y Paleontología, Facultad de Ciencias, Campus de Fuentenueva s.n., Universidad de Granada, 18002 Granada, Spain; jaguirre@ugr.es

${ }^{3}$ Department of Geology, Naturalis Biodiversity Center, Postbus 9517, 2300 RA Leiden, The Netherlands; steve.donovan@ naturalis.nl

${ }^{4}$ Instituto de Geología, Estación Regional del Noroeste, Universidad Nacional Autónoma de México, Av. Luis Donaldo Colosio M. esq. Madrid s/n, Campus UNISON, Apdo. 1039, 83000, Hermosillo, Sonora, México; png@ugr.es

${ }^{5}$ UEI-Departamento de Paleontologia (CSIC-UCM), Facultad de Ciencias Geológicas, Universidad Complutense, Ciudad Universitaria s/n, 20816 Madrid, Spain; sergrodr@geo.ucm.es

* Corresponding author
}

Laborda-López, C., Aguirre, J., Donovan, S.K., Navas-Parejo, P. \& Rodríguez, S. 2015. Fossil assemblages and biostratigraphy of metamorphic rocks of the Nevado-Filábride Complex from the Águilas tectonic arc (SE Spain). [Asociaciones de fósiles y bioestratigrafía de las rocas metamórficas del Complejo Nevado-Filábride del arco tectónico de Águilas (SE de España)]. Spanish Journal of Palaeontology, 30 (2), 275-292.

\section{ABSTRACT}

Abundant marine macrofossils are present in graphitic marbles and calc-silicate schists belonging to the Veleta nappe of the Nevado-Filábride Complex (Internal Zones of the Betic Cordillera, SE Spain), in what is called the Águilas tectonic arc. These fossils have resisted metamorphism and deformation, and in some instances have been finely preserved. The fossil assemblages are dominated by crinoids, followed by minor cephalopods, brachiopods, rugose corals, and putative sections of trilobites. In addition to these confidently identified groups, there are other fossil represented, but deformation and extensive recrystallization have destroyed anatomical characters, hampering their taxonomic identification. Among the crinoids, the columnal parataxa Pentagonopentagonalis (col.) and Bystrowicrinus

\section{RESUMEN}

Los mármoles grafitosos y calcoesquistos pertenecientes al manto del Veleta del Complejo Nevado-Filábride (Zonas Internas de la Cordillera Bética, SE de España) del denominado arco tectónico de Águilas contienen un abundante registro de macrofósiles marinos. Dichos fósiles han estado sometidos a un proceso de metamorfismo y deformación y, aún así, en algunos casos, se han preservado de forma excepcional. Las asociaciones fosilíferas están dominadas por crinoideos seguidos en menor proporción de cefalópodos, braquiópodos, corales rugosos y secciones de trilobites. Además de estos grupos, que han sido identificados con un alto nivel de fiabilidad, hay otros que no han podido ser clasificados con certeza debido a que la intensa deformación y recristalización que afectó a las 
(col.) have been recognized. Planispiral cephalopods, assigned to either primitive ammonoids attributable to the order Agoniatitid (one of them being a possible member of the family Mimosphinctidae) or coiled nautilids, as well as orthoconid sections of possible orthoceratids or bactritids are present. Finally, there are rugose corals attributable to the family Phillipsastreidae, possibly Peneckiella. Among the remains with obscure taxonomic assignment, we recognize possible laminar calcareous algae and benthic foraminifers. Finally, irregular, massive structures showing a rough laminar organization and longitudinal tubes with rounded sections are found in some black marble beds. These can be identified either as possible chaetetids or bryozoans. The report of these taxa has limited the rocks studied to the Emsian, late Early Devonian.

Keywords: Invertebrate fossils, Early Devonian, Internal Zones, Murcia, Betic Cordillera. rocas han obliterado los caracteres anatómicos diagnósticos. Por tanto, su identificación taxonómica es más complicada. Entre los crinoideos, se han identificado dos parataxones columnares, Pentagonopentagonalis y Bystrowicrinus. Se han reconocido cefalópodos planiespiralados, identificados como ammonoideos primitivos atribuibles al orden Agoniatitida (uno de ellos posiblemente pertenece a la familia Mimosphinctidae) o nautílidos planiespiralados, al igual que secciones ortocónidas de posibles ortoceratítidos o bactrítidos. Finalmente, los corales rugosos corresponden a la familia Phillipsastreidae, entre ellos al género Peneckiella. Entre los restos no identificables hemos reconocido posibles algas calcáreas laminares y foraminíferos bentónicos. Por último, en los niveles de mármoles grafitosos se encuentran unas estructuras masivas e irregulares que muestran una laminación horizontal y tubos verticales de sección redondeada. Pueden ser tanto posibles chaetétidos como briozoos. La asociación de fósiles estudiada permite limitar la edad de las rocas estudiadas al Emsiense (Devónico inferior).

Palabras clave: Fósiles de invertebrados, Devónico inferior, Zonas Internas, Murcia, Cordillera Bética.

\section{INTRODUCTION}

Both the age and the tectonic and stratigraphic arrangement of the entire metamorphic Nevado-Filábride Complex of the Betic Cordillera (S Spain) have been hotly debated (e.g., Egeler \& Simon, 1969; Puga, 1977, 1990; GómezPugnaire et al., 1982; Tendero et al, 1993; Azañón et al., 2002; Martínez-Martínez et al., 2002, 2010; Aerden \& Sayad, 2008; Gómez-Pugnaire et al., 2012; Platt et al., 2013). In the most recent studies, Gómez-Pugnaire et al. (2012) for example, show that the entire complex is Palaeozoic in age (and even older) while Platt et al. (2013) attributed a Palaeozoic-Late Triassic age. Although a few biostratigraphical results are available (Lafuste \& Pavillon, 1976; Gómez-Pugnaire et al., 1982; Tendero et al., 1993), the chronological discussion is based mostly on radiometric dating of metamorphic zircons and igneous rocks intruded in the metamorphic rocks. However, processes such as intense deformation, overlapping of tectonic phases, superposition of several orogenic events, or pervasive recrystallization might bias the radiometric dating of the metasediments (e.g., Martínez-Martínez et al., 2010). In addition, establishing an age for the igneous rocks intruded in the host metasediments does not allow the metamorphic rocks to be dated. This method provides only a minimum age of the host rocks. Finally, faulting, folding, and thrusting substantially distort the stratigraphic sequence of the metamorphic rocks obscuring the relative position of the different materials.
As a general rule, biostratigraphic criteria are usually discarded in order to date metamorphic terrains since fossils are prone to be destroyed during metamorphism (Moorbath, 2005; Bernard et al., 2007, 2010; Javaux \& Benzerara, 2009; Galvez et al., 2012; Schiffbauer et al., 2012). This assumption, although essentially true, is often overemphasized. It is well known that palynomorphs or conodonts in Triassic-Palaeozoic rocks can survive metamorphism. In addition to these microfossils, macrofossils can be also exceptionally preserved in metamorphic rocks of variable degrees (Sharpe, 1847, 1849; Daubrée, 1876; Bucher, 1953; Termier \& Termier, 1970; Hill, 1985; Pflug \& Reitz, 1987; Hanel et al., 1999; Bernard et al., 2007, 2010; Cavargna-Sani et al., 2010; Galvez et al., 2012). The exceptional occurrence of fossils in metamorphic rocks raises the possibility of dating them using conventional biostratigraphic methods.

This is particularly true of the metamorphic rocks belonging to the Nevado-Filábride Complex (NFC hereafter) of the Internal Zones of the Betic Cordillera that crops out extensively in what is called the Águilas tectonic arc (SE Spain) (Fig. 1a). These rocks have undergone a complex metamorphic history involving different degrees of metamorphism and intense deformation during the Variscan and Alpine orogenies (Gómez-Pugnaire \& Franz, 1988; Gómez-Pugnaire et al., 2000, 2004, 2012; SánchezVizcaíno et al., 2001; Platt et al., 2013). Despite these processes, rich and diverse fossil assemblages have been preserved in black marbles and calc-silicate schists. 


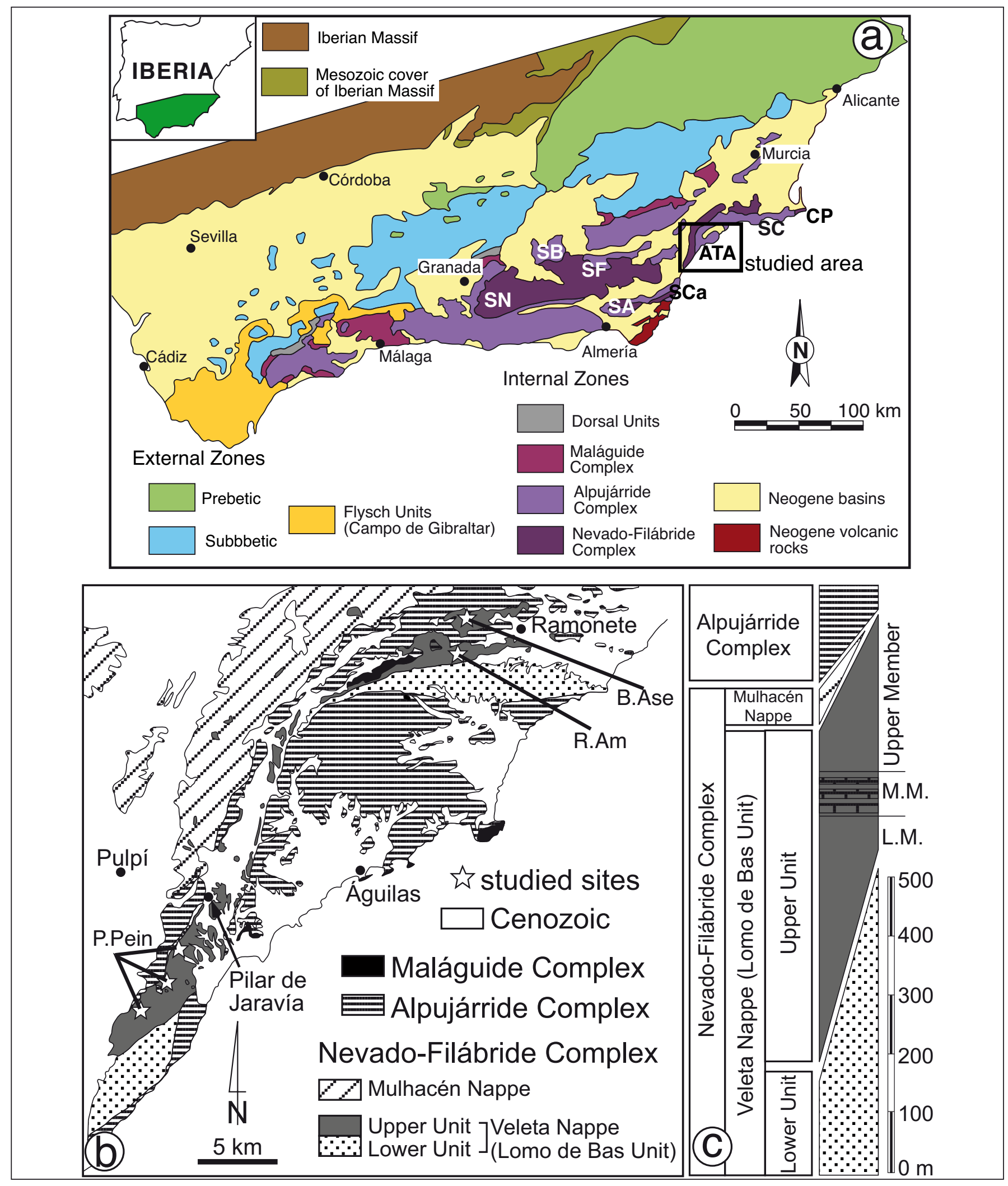

Figure 1. Location and geological context of the study area. a) Geological map of the Betic Cordillera in S Spain. The square at the eastern part of the cordillera represents the study area, which is detailed in Fig. 1b. SN- Sierra Nevada; SB- Sierra de Baza; SF- Sierra de los Filabres; SA- Sierra Alhamilla; SCa- Sierra Cabrera; ATA- Águilas tectonic arc; SC- Sierra de Cartagena; CP- Cabo de Palos. b) Geological map of the Águilas tectonic arc indicating the location of the study sections. B.AseBarranco de los Asensios section; R.Am- Rambla del Río Amir section; P.Pein- Puerto de los Peines composite section. c) Simplified stratigraphic log of the Nevado-Filábride Complex in the study area. Separation among different units represents tectonic contacts. L.M.- lower member; M.M.- middle member. 
Lafuste \& Pavillon (1976), referring to the work previously performed by Danto (1973), mentioned the presence of macrofossils in the black marbles of an abandoned quarry (here referred to as Barranco de los Asensios section; see below). These authors cited only the presence of marine macrofossils, while highlighted the unsuccessful search for conodonts and pollen. Also, they emphasized that deformation and recrystallization precluded a precise identification of these fossils. However, these authors cited the presence of evident crinoid ossicles and gastropods, as well as doubtful sections of brachiopods, spiriferids among them, and orthoceratids. In addition, they described in detail a massive organism with an internal organization consisting of tubes that were irregular to polygonal in section. Based on the arrangement and size of the tubes, Lafuste \& Pavillon (1976) identified it as a chaetetid colony, Chaetetes cf. salairicus, Dubatolov, allowing them to assign the black marbles to the Eifelian (lower Middle Devonian). Unfortunately, these authors did not provide any picture or description of the fossils and, regarding the chaetetid, they referred to only one specimen figured only with two drawings, making it difficult to reasonably test their interpretation.

Recently we have revisited the sites originally studied by Lafuste \& Pavillon (1976) and have discovered new localities that contain additional faunal remains that add to our knowledge of the fossil assemblages preserved in these metamorphic rocks of the NFC. During the fieldwork, we found that macrofossils are unexpectedly abundant and, in some cases, well preserved (Laborda-López \& Aguirre, 2013; Laborda-López et al., 2013, 2014, 2015). In this paper, we present an in depth description and a critical taxonomic review of the faunal assemblages, focusing both on those groups of organisms that can be reliably identified as well as on those that are of doubtful taxonomic assignment. The main aim of this paper is to update the taxonomic list of the faunal assemblages, which in turn is critical to re-evaluate the biochronological meaning of these faunas.

\section{LOCATION AND GEOLOGICAL SETTING}

The study area is close to the border between Murcia and Almería provinces (SE Spain). The sections studied crop out along the Águilas tectonic arc, in an arched NE-SW cartographic belt extending from near Ramonete (Lorca, Murcia) to Sierra del Aguilón, (Pilar de Jaravía, Almería) (Figs 1a-1b). These outcrops are part of the metamorphic hinterland of the Internal Zones of the Betic Cordillera.

The Betic Cordillera is in the westernmost part of the circum-Mediterranean Alpine Orogen. This mountain range is the result of the collision of the Iberian and African plates during the Neogene. The Betic Cordillera is divided into two major palaeogeographic-tectonic domains, the External Zones and the Internal Zones (Fig. 1a). The Internal Zones consist of three superimposed tectonic complexes: from bottom to top, the Nevado-Filábride, the Alpujárride and the Maláguide complexes (Fig. 1a). The two former tectonic complexes are metamorphosed to variable degrees, while the later is not or only slightly metamorphosed. Beyond these three units, an additional stack of tectonic wedges of sedimentary rocks has been proposed as belonging to the Internal Zones: the Dorsal and pre-Dorsal units (Wildi, 1983; Martín-Algarra \& Estévez, 1984; De Wever et al., 1985). The Dorsal and pre-Dorsal units are formed by Mesozoic-Cenozoic (Early Miocene) sedimentary successions rimming the contact between the External Zones and the Maláguide Complex with an unresolved tectonic evolution and a very obscure palaeogeographic significance (Platt et al., 2013).

The rocks studied belong to the innermost NFC, which forms the cores of tectonic domes that, in turn, represent the major mountain ranges of the Betic Cordillera: Sierra Nevada, Sierra de los Filabres, Sierra Alhamilla, Sierra Cabrera, Águilas tectonic arc, Sierra de Cartagena, and Cabo de Palos (Fig. 1a). The NFC was part of the Iberian Massif palaeomargin (Gómez-Pugnaire et al., 2004, 2012; Booth-Rea et al., 2007; Behr \& Platt, 2013; Platt et al., 2013). It is formed by two nappes, i.e., the Veleta nappe in the bottom, which is overlain by the Mulhacén nappe (Fig. 1c). The materials studied belong to the Veleta nappe, which underwent metamorphism to green-schist facies (350-480 C; $2 \mathrm{~Kb}$ ) (Sánchez-Vizcaíno et al., 2001).

In the study region, the Veleta nappe, defined as Lomo de Bas Unit (Álvarez \& Aldaya, 1985; Álvarez, 1987), consists of two overlying units superposed by tectonic contacts (Fig. 1c). The lower unit consists of an alternation of quartz-schist, garnet and chloritoidschist, ferruginous quartzite levels, and dikes of acid metavolcanic rocks. The base of this unit is unknown and its outcrop thickness is more than $1,000 \mathrm{~m}$. The upper unit is divided into three members (Fig. 1c). The lower member consists of fine-grained metasediments, mostly graphite micaschists, quartzschists, metapsammites, and phyllites, which intercalate ferruginous quartzite beds. The middle member is made up of phyllites, metapsammites, and black mica schists that intercalate massive beds of graphite black marbles and calc-silicate schists. The upper member is formed by dark graphite schist and phyllites, with intercalations of quartzites.

The tectonic boundary between the Veleta and Mulhacén nappes is located in the top of the upper member. The Mulhacén nappe consists of coarse-grained graphite schists, orthogneisses, and marbles. Finally, dolostones of the Alpujárride Complex overlie the materials of NFC (Fig. 1c). 


\section{DESCRIPTION OF THE STUDY SECTIONS}

Three sections have been studied: the Rambla del Río Amir, the Barranco de los Asensios, and the Puerto de los Peines composite section (Fig. 2). The Puerto de los Peines section is near to Pilar de Jaravía (Pulpí, Almería) and the other two sections are located close to Ramonete (Lorca, Murcia) (Fig. 1b). In all these sections, the carbonates of the middle member of the Veleta nappe contain rich fossil assemblages, which are the subject of this paper. The thickness of the middle member ranges from $40 \mathrm{~m}$ (in Barranco de los Asensios section) to $350 \mathrm{~m}$ (in Puerto de los Peines section) (Fig. 2). In both the Puerto de los Peines and Rambla del Río Amir sections, the middle member consists of massive graphitic marble and calc-silicate schist beds interspersed between metapsammites and fine-grained, black, graphitic schist and phyllites. Some quartzite and red marble beds are also intercalated. Marble beds range from 0.5 to $5 \mathrm{~m}$ in thickness in the Rambla del Río Amir section, and up to $20 \mathrm{~m}$ in Puerto de los Peines section. The marble beds are intensely recrystallized and deformed, with strong foliation. Massive carbonate beds show boudinage due to stretching and shearing but they can be followed laterally, although discontinuously, for dozens of kilometres.

In the Barranco de los Asensios section, massive marble beds represent the middle member (Fig. 2). Laterally, some calc-silicate schist beds are intercalated in the marbles. Here, recrystallization and deformation are not so intense and fossils are consequently better preserved than in the other two sections.

The most abundant and diverse fossil assemblage is found in the Barranco de los Asensios section; crinoids, cephalopods, brachiopods, rugose corals, trilobites, gastropods and possible benthic foraminifers. Laminar structures appear to be related to algal thalli, but recrystallization has precluded a confident identification. Finally, massive (nodular, dome, laminar and irregular), finely laminated structures occur scattered in some carbonate beds. Their original inner anatomical details are lost due to recrystallization, preventing an accurate identification. Nonetheless, "ghosts" (relicts) of tubular elements with rounded sections are locally preserved. Based on the outline, the inner arrangement and the size of the tubular elements, these structures could be identified either as chatetids or as bryozoans.

In the Puerto de los Peines and Barranco del Río Amir sections, fossil assemblages are dominated almost exclusively by crinoids. They occur both in the calcsilicate schist beds and in the massive marbles. However, preservation of crinoids in the calc-silicate schist is rather different from those in the massive marble beds (LabordaLópez \& Aguirre, 2013; Laborda-López et al., 2013, 2014, 2015). Crinoids in the calc-silicate schist beds occur concentrated mostly at the base of the beds, while in the massive carbonate beds they are scattered. In addition, a few specimens of brachiopods and possible rugose corals also occur in these two sections.

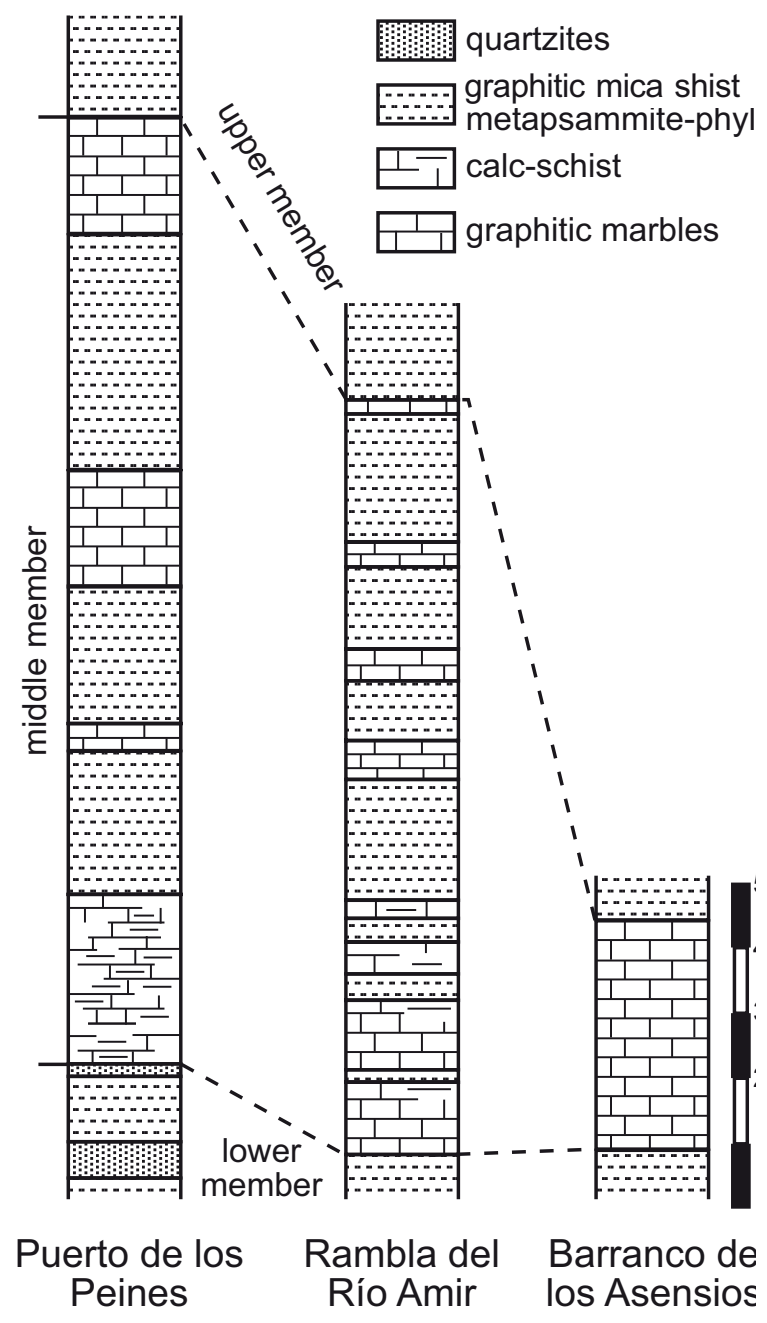

Figure 2. Stratigraphic sections of the middle member in the study sites.

\section{MATERIALS AND METHODS}

During fieldwork, the original localities described by Lafuste \& Pavillon (1976) were revisited and new sites were identified. Stratigraphic logs and sampling were performed in the selected areas. The sampling effort focused on the metamorphic carbonates, which offered the best preserved and the richest fossil assemblages were found. Also, we sampled the fine-grained micaschist and phyllites of this unit in order to identify palynomorphs, acritarchs, and/ or spores; in addition, we sampled the graphitic marbles in search of conodonts (works in progress). We also analysed microfacies and micropalaeontological (benthic 
foraminifera) content in 23 thin sections. All samples were processed and stored in the Dpto. de Estratigrafía y Paleontología of the University of Granada.

\section{PALAEONTOLOGiCAL CONTENT}

\subsection{Recognizable taxa. Description and interpretation}

The description of the identifiable taxa is based on the relative abundance in the study sections.

\subsubsection{Crinoids}

The most abundant fossil remains are crinoids. When deformation is not so intense, the original carbonates appear to be dominated by crinoids, producing a metasedimentary rock similar to encrinite deposits. Crinoids occur as isolated as well as articulated columnal and brachial ossicles. Two columnal parataxa have been confidently recognized. The first type consists of stem ossicles, $1 \mathrm{~cm}$ in diameter, displaying a pentagonal or rounded pentagonal outline. The lumen shows a characteristic regular pentagon or flower-like morphology (Figs 3a-3b). The facet is not crenulated and does not show an apparent epifacet or areola (Fig. 3b). Based on these features, they are attributed to Pentagonopentagonalis (col.) sp. columnal parataxon.

The second type of columnal elements is about $2 \mathrm{~cm}$ in diameter. The facet is circular or pentagonal with a pentastellate axial canal (Figs 3c-d). The facet is finely crenulated, with a radial arrangement of crenula without an epifacet. Areola rounded. These columnal elements are assigned to the parataxon Bystrowicrinus (col.) sp.

Further disarticulated crinoid elements, small plates displaying hook or horseshoe morphology, have been found (Figs 3e-3f). These elements may be either brachial ossicles or columnals of small crinoids. Rarely, articulated portions of these small crinoid elements (= pluricolumnals) are also present (Fig. 3g). The morphology by itself is not indicative of any particular taxa. In addition, plate-like elements are also dispersed (Fig. 3h). They do not show any characteristic morphology, but preserve the typical inner arrangement of echinoderm plates. They may be the plates of crinoid calyxes.

In addition to these isolated parataxa, large portions of pluricolumnal stems of about $3.5 \mathrm{~cm}$ in diameter have been found. Based on the large size of these stems they can be confidently attributed to camerate or cladid crinoids.

In the Puerto de los Peines section, a cup-shaped structure, about $11 \mathrm{~cm}$ in length and $8 \mathrm{~cm}$ in maximum width, has been found (Fig. 4a). At the base of the cup, a star-like structure is clearly recognized (Figs 4a-4b). A folded tubular funnel connects with the base of the cup and a protruding tuft-like structure rises from the top of the cup (Fig. 4a). At higher magnification, the internal microstructure has been preserved, showing the typical porous skeleton of crinoid stereom (Figs 4b-4c). Therefore, based on the general shape and the inner microstructure, the whole formation can be interpreted as a complete calyx, most likely belonging to a camerate or cladid crinoid, preserving part of the stem (the furrow) and the brachial system (the tuft-like structure). The star-like structure is interpreted as the basal plate of the calyx.

In the same section, another putative portion of a partially articulated calyx has been found (Fig. 4d). It is triangular in shape with a maximum length of $4.5 \mathrm{~cm}$. The sutures of the plates are clearly visible (Fig. 4d). At the base of this triangular plate, the crinoid stem is preserved in connection with the calyx. In the upper part of the calyx plate, what appears to be part of the brachial system is also present (Fig. 4d).

In addition, some bell-shape fossils have been found. The general morphology and outline suggest collapsed crinoid calyxes, but extreme deformation precludes any reliable identification.

\subsubsection{Rugose corals}

After crinoids, rugose corals are the next most abundant organisms in the fossil assemblage (Fig. 5a). They are abundant in the graphitic marble beds of the Barranco de los Asensios section. They are colonial corals showing a fasciculate habit. The corallites are $2-3 \mathrm{~cm}$ in diameter. Although partially deformed, a radial internal arrangement of the septa is evident. The corallites show a narrow peripheral area of poorly developed dissepiments (Figs $5 b-5 c)$. Tabulae are not well preserved, but they seem to be basically horizontal. In oblique section, the external wall (theca) is visible in one specimen. Under the microscope, the internal organization is obliterated due to recrystallization, although thin and long septa, reaching almost the axis of the coral, are vaguely discernible (Fig. 5d). These specimens are identified as rugose corals belonging to the family Phillipsastreidea, probably a species of the genus Peneckiella.

\subsubsection{Cephalopods}

Sections of coiled shells are found in the Barranco de los Asensios section (Figs 6a-6b). They are planispiral, advolute showing inner chambers filled up with calcite and the outer chamber filled with sediment. This filling pattern indicates that the calcite-filled chambers correspond to the phragmocone and the sediment-filled last chamber is the body chamber of cephalopods. One of the specimens is 

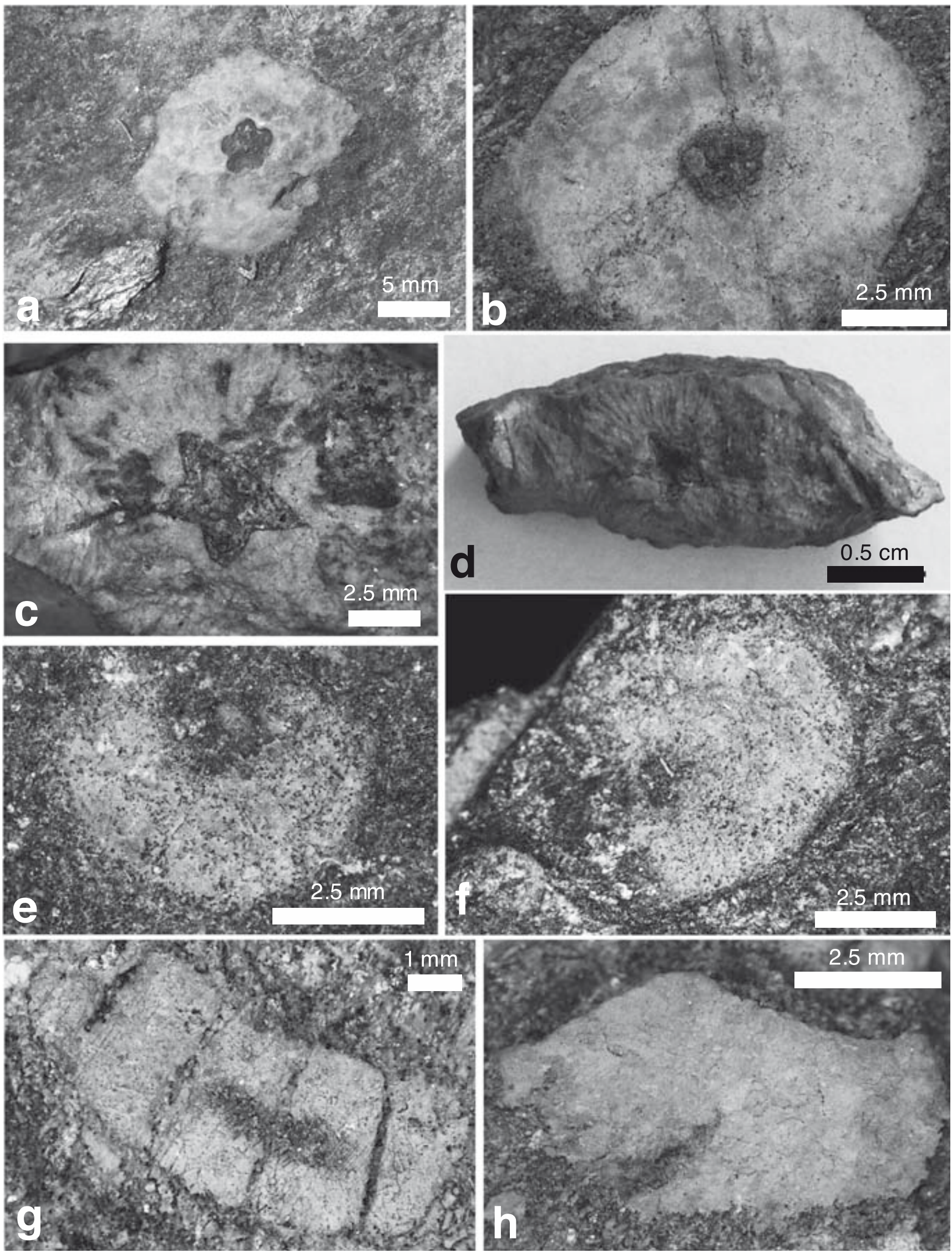

Figure 3. Crinoid elements. a-b) Pentagonopentagonalis (col.) sp. c-d) Bystrowicrinus (col.) sp. e-f) Small elements attributed to either brachial ossicles or columnals of small crinoids. g) Portion of articulated arm ossicles or small crinoid elements. h) Polygonal element interpreted as a calyx plate. 

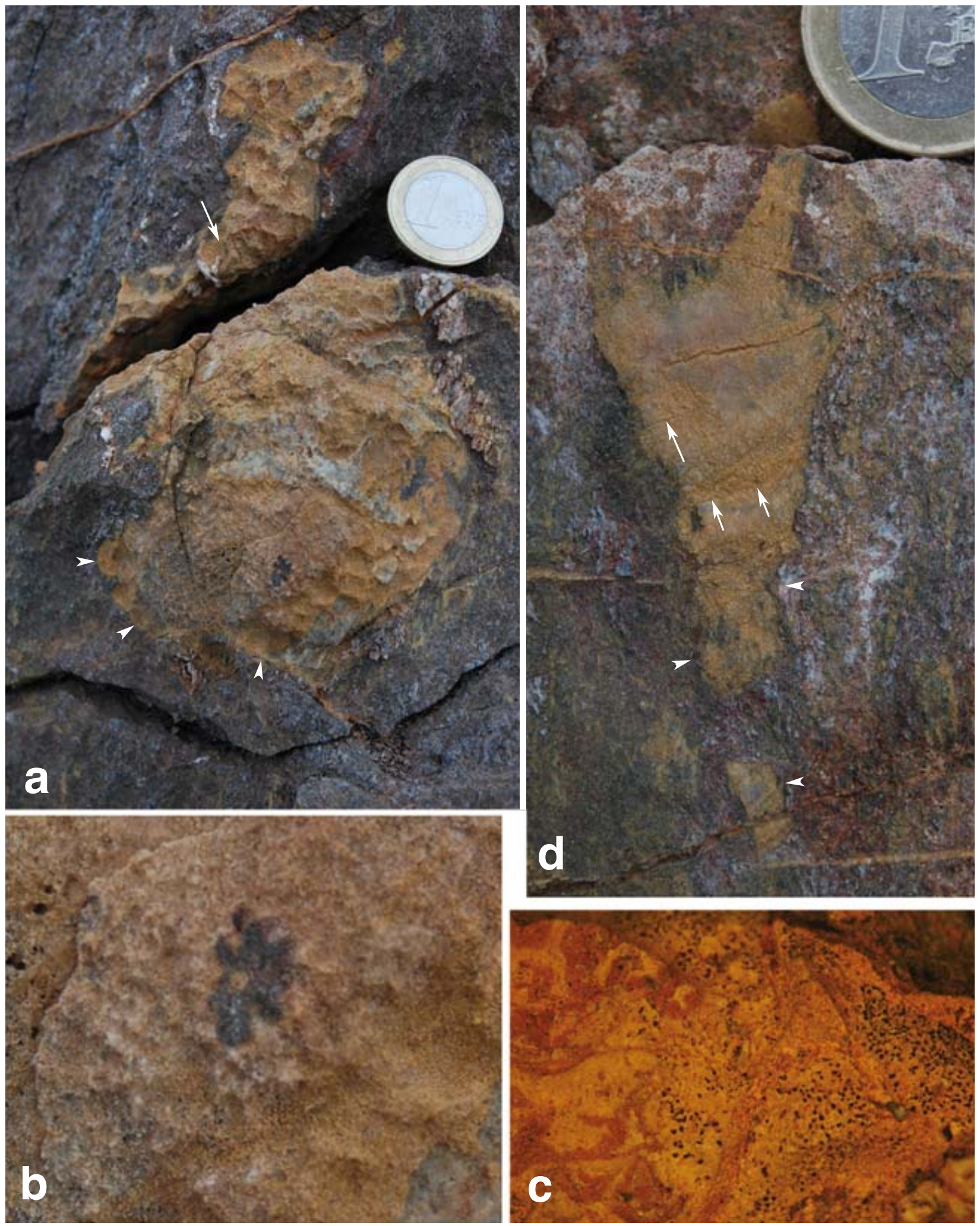

Figure 4. a) Cup-like test interpreted as a complete calyx of a putative camerate crinoid. In the upper part of the organism, a tuft-like protruding structure is prominent. It is attributed to part of the brachial apparatus (arms). In the lower part, and surrounding part of the cup (arrowheads) a furrow is recognized. It is believed to be part of the stem of the crinoid. Finally, also at the base of the cup, there is a star-like structure. It is identified as the basal plate of the calyx. The arrow marks the place of the picture in (c). b) An enlargement of the stellate basal plate. Surrounding this basal plate, the skeleton is porous, showing the characteristic crinoid stereom. c) Close-up view under a lens of the crinoid stereom [arrow in (a)]. d) Portion of another crinoid calyx. The stem is clearly articulated at the lower part of the structure (arrowheads). Internally, the sutures of the calyx plates are also visible (arrows). 

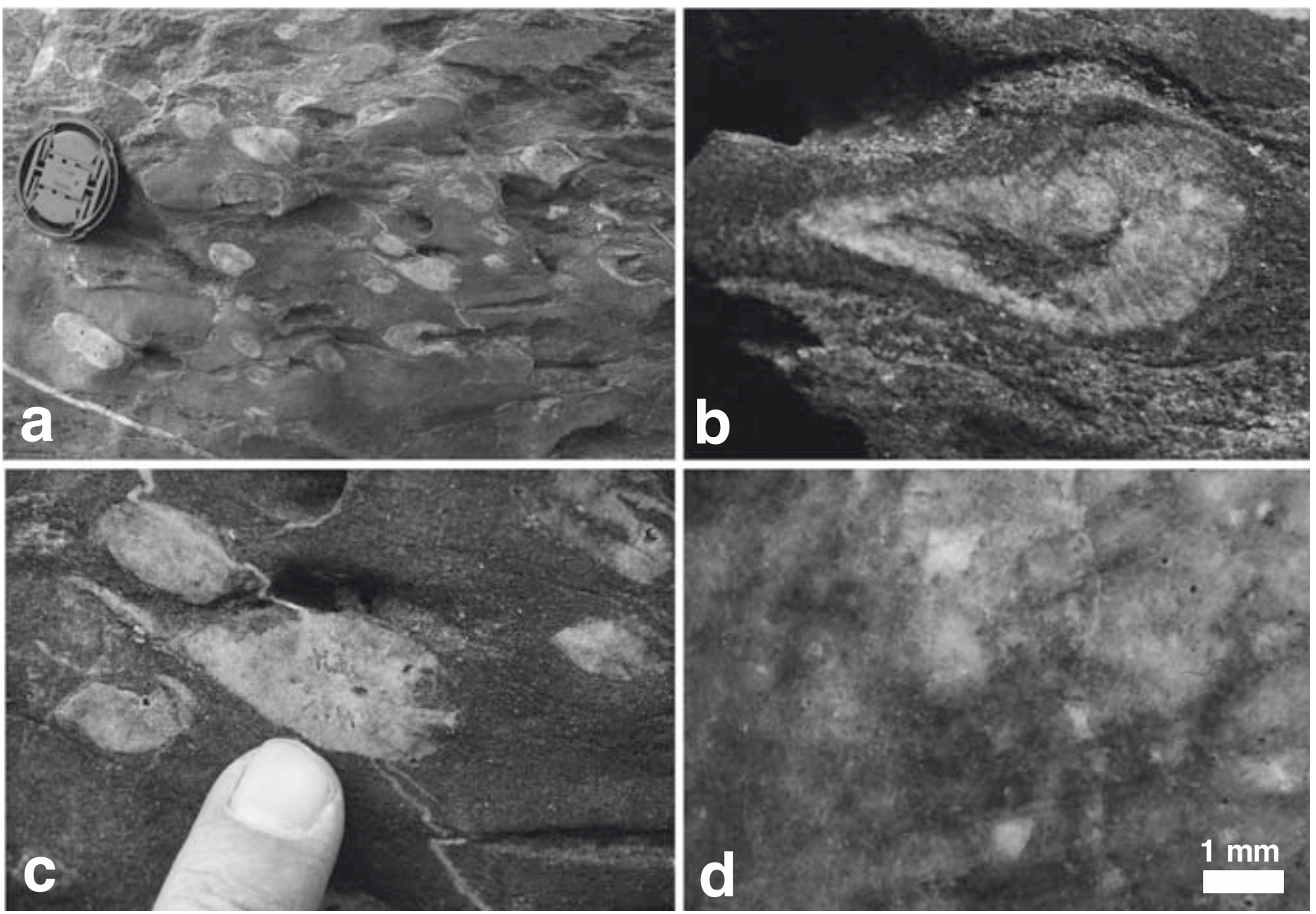

Figure 5. Rugose corals from the Barranco de los Asensios section identified as members of the family Phillipsastreidea, most likely belonging of the genus Peneckiella. a) Field view of an accumulation of rugose corals in a massive marble bed. Lens cap is $58 \mathrm{~mm}$ in diameter. b-c) Detailed view of two corals showing the internal radial arrangement of the septa (specimen in $\mathbf{b}$ is $2 \mathrm{~cm}$ in length). d) Relics of septa preserved in a rugose coral.

$6 \mathrm{~cm}$ in largest diameter and shows a small $(<10 \mathrm{~mm})$ enclosed umbilical window (Fig. 6a). The chambers of the phragmocone are collapsed and the body chamber is slightly separated from the phragmocone (Fig. 6a). This separation is not due to deformation since it is oblique to the collapsed chambers; therefore, it is an original anatomical feature of the shell. The planispiral advolute coiling, with loose, only tangential contact between adjacent whorls, together with the small-enclosed umbilical void and the separation of the outer whorl from the phragmocone allow the assignment of these specimens to primitive ammonoids of the order Agoniatitida. Considering that primitive ammonoids show a great intraspecific variability (De Baets et al., 2013), our specimen shows close similarities with the genera Erbenoceras or Chebbite of the family Mimosphinctidae.

However, a possible taxonomic attribution to nautiloids cannot be completely discarded since the specimen of Fig. $6 \mathrm{a}$ shows similar morphological features as some Lower Devonian nautiloids.

Further cephalopods, oval in section and $1.5 \mathrm{~cm}$ in diameter, with recognizable septa, as well as conical, longitudinal sections have also been identified in the Barranco de los Asensios section (Figs 6c-6d). The presence of internal septa separating chambers indicates that these specimens are cephalopods. According to the general shell morphology, they are assigned to orthoconid cephalopods, such as orthoceratids or bactritids.

\subsubsection{Gastropods}

Sections of spiral shells without internal walls and completely filled of sediment have been found (Fig. 7c). Absence of any internal partition identifies these sections as presumed gastropods.

\subsubsection{Trilobites}

Among the recognizable fauna, a section confidently attributable to a trilobite has been found (Fig. 6e). The section shows a trilobate skeleton, with a thickened central part and thinned lateral flanks. The outline of this specimen is comparable to trilobite sections, as shown by 

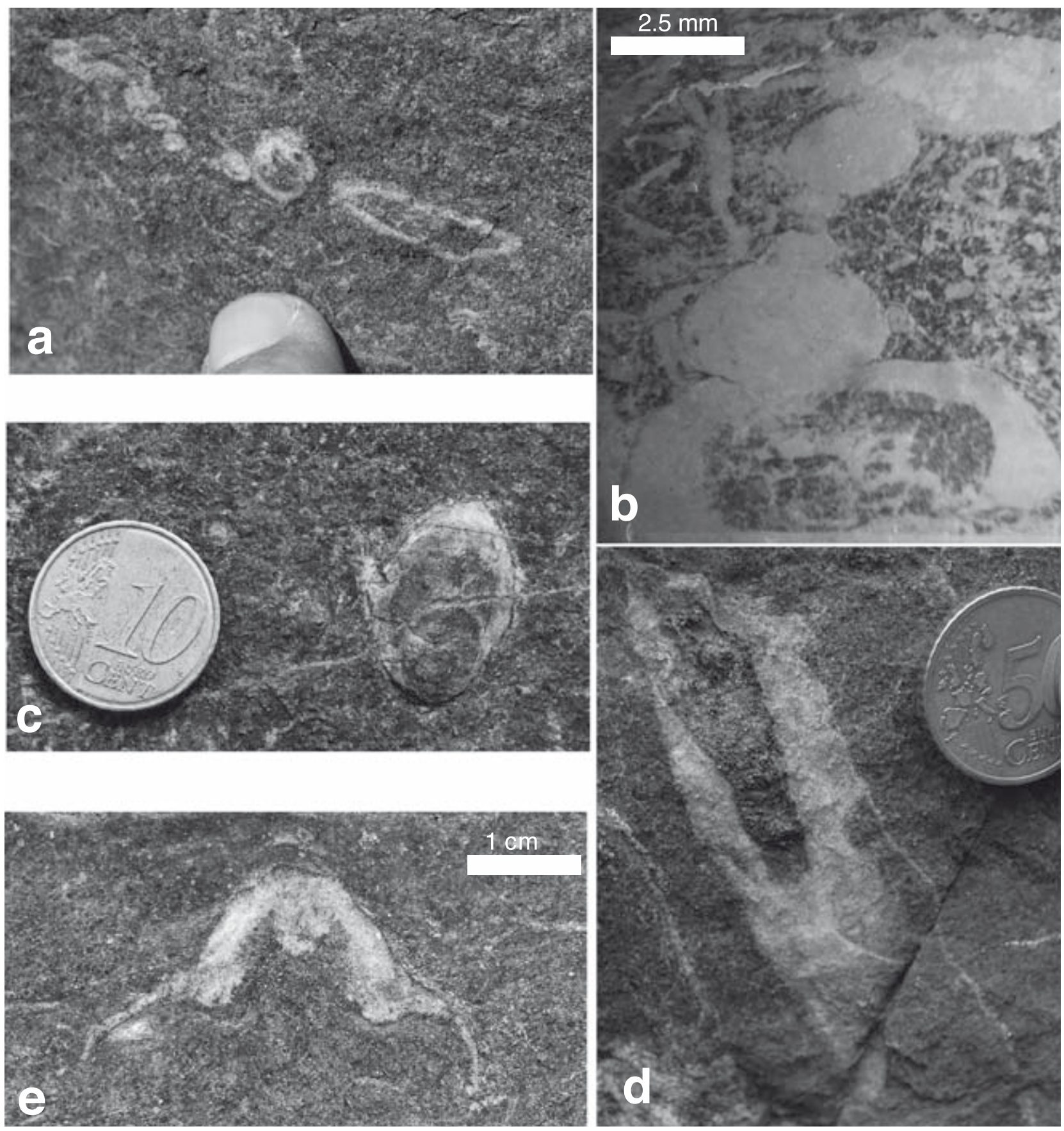

Figure 6. a) Section of a deformed ammonoid. Note the presence of a small umbilical void. The inner whorls are tangentially arranged, indicating a planispiral advolute growth. In addition, the last whorl is slightly separated from the rest of the shell. All these characteristics indicate that this specimen is most likely a member of the family Mimosphinctidae, such as Erbenoceras or Chebbites. b) Section of another planispiral advolute ammonoid in thin section. The inner chambers filled with calcite correspond to the phragmocone and the last one occupied by sediment is the living chamber. It is a putative representative of the order Agoniatitida. c-d) Oblique (c) and longitudinal (d) sections of orthoceratids. A septum is visible in the interior of the shell in (c). e) Section of a trilobite. The protuberant structures at the base of the skeleton mark the possible apodemes of the trilobite cephalon.

Flügel (2002, plate 94, fig. 1). The thickened portions at the intersections of the central lobe with the lateral parts can be feasibly interpreted as the apodemes (Fig. 6e), knob-like constructions in the ventral side of the trilobite cephalon in contact with the hypostome. In addition, several sections of thin skeletons showing a characteristic hook-like morphology are also present. These sections, although impossible to confidently assign to any specific group of organisms, recall sections of trilobites, similar to those shown by Flügel (2002, plate 94). One of the main 
problems with the reliable taxonomic attribution of these sections is that the internal microstructure has been effaced by recrystallization.

\subsubsection{Brachiopods}

There are also sections of bivalved organisms with relatively thick shells (Figs 7a-7b). The outline morphology is variable, with sections showing heart-like (Fig. 7a), elongated or trapezoidal biconvex shapes. In one specimen, an internal crest is evident that might correspond to the support of the lophophore, to a median ridge or to part of an interior spondylium (Fig. 7b). The shell microstructure has been completely obliterated due to recrystallization. They can be confidently identified as brachiopods.

\subsection{Organisms of doubtful taxonomic attribution}

In addition to the reliably identified fossils, there are numerous fossil remnants that are taxonomically obscure. Substantial distortion of the external outlines of the fossil remains due to deformation, as well as destruction of their internal structure by pervasive recrystallization, accounts for the difficulties in taxonomic identification.

Contorted laminar structures are found in the marble beds (Figs $8 \mathrm{a}-8 \mathrm{~b}$ ). The arrangement of these structures does not follow either mineral fillings in fractures or folded veins of calcite. This strongly suggests that they are most likely organic in origin. Macroscopically, the external morphology looks like laminar algal thalli. Nonetheless, obliteration of any inner anatomical trait due to recrystallization impedes a confident identification.

In the Barranco de los Asensios section, massive structures up to several dozens $\mathrm{cm}$ in cross section are found. These are abundant in several beds of massive black marbles (Figs 9a-9b). The shape of these structures is highly variable: nodular, domed, mushroom-like, flat or irregular. They are made up of encrusting organisms that show a rough internal concentric lamination and vertical walls oriented perpendicular to the outer surface (Figs 9c9d). Examination by transmitted light microscopy shows the entire internal structure to have been obliterated by recrystallization (Fig. 10a). However, using a piece of white paper as light diffuser (following the methodology proposed by Delgado, 1977), 'ghosts' (relicts) of the original inner arrangement become evident (Fig. 10b). They have tubular elements perpendicular to the outer surface measuring about $200 \mu \mathrm{m}$ (Fig. 10c). These elements are separated by walls, $80-120 \mu \mathrm{m}$ in thickness. In transverse section, the tubes show rounded to polygonal shapes (Fig. 10d). Based on the external morphology, the internal organization and size of the inner elements, these organisms are similar to calcareous chaetetid sponges. They fit with the original description of Chaetetes cf. salairicus by Lafuste \& Pavillon (1976). Nonetheless, they are also close to bryozoans (perhaps members of the order Cryptostomata).

Finally, in thin sections, ovoid, circular and spiral sections range from about $100 \mu \mathrm{m}$ to $200 \mu \mathrm{m}$ in size (Figs 11a-11b). These show granular black walls, and internally, some of the elongated and spiral sections present inner chambers separated by walls showing similar characteristics as the external wall. We interpret them as sections of agglutinated benthic foraminifers.

\section{DISCUSSION}

Regarding the biochronology of the NFC, few data are available. In the study region, Lafuste \& Pavillon (1976) attributed the marbles to the Eifelian (Middle Devonian) based on the record of the chaetetid Chaetetes cf. salairicus Dubatolov.

In Sierra de Baza (westernmost sector of Sierra de los Filabres, SE Spain; Fig. 1a), Gómez-Pugnaire et al. (1982) attributed an age of Late Riphean (= Early Neoproterozoic) to NFC rocks included in the lowermost part of the Veleta nappe. This was based on the presence of the palynomorphs Gloecapsomorpha sp. and Trematosphaeridium sp., as well as algal trychomes and unidentifiable taxa of the family Sphaeromorphidae.

Finally, north of Cóbdar, a locality of Sierra de los Filabres, Tendero et al. (1993) described ankeritic objects in marble beds intercalated in black quartzite and calcsilicate schist of the NFC. According to these authors, the ankeritic bodies recall Cretaceous planktonic foraminifers ("globotruncanids" sensu lato) belonging to Rotalipora or Praeglobotruncana of the Albian-Turonian, as well as forms resembling Helvetoglobotruncana helvetica (Bolli) of the middle Turonian or Hedbergella from the Aptian to Maastrichtian (Senonian sensu Tendero et al., 1993).

The data on fossil assemblages presented in this paper can help to confidently unravel the chronology of the carbonates of the upper unit of the Veleta nappe in the Águilas tectonic arc (Fig. 12). The fossils discussed above clearly show a Palaeozoic age for these rocks. This, in turn, agrees with the Palaeozoic and older age attribution to the NFC as an entire tectonic unit (Gómez-Pugnaire et al., 1982, 2000, 2004, 2012; Gómez-Pugnaire \& Franz, 1988; Platt et al., 2013). The most reliable biochronological data are those provided by the firmly identified crinoids. Bystrowicrinus (col.) sp. indicates a maximum age range Late Ordovician-Early Carboniferous (Mississippian) (Yeltysheva \& Stukalina, 1963; Donovan \& Wright, 1995; Donovan, 2012, 2013) and Pentagonopentagonalis (col.) sp. implies a maximum age range Late Ordovician-Middle Devonian (Yeltyseva, 1955; Donovan \& Harper, 1992; Kurilenko \& Kulkov, 2008). 

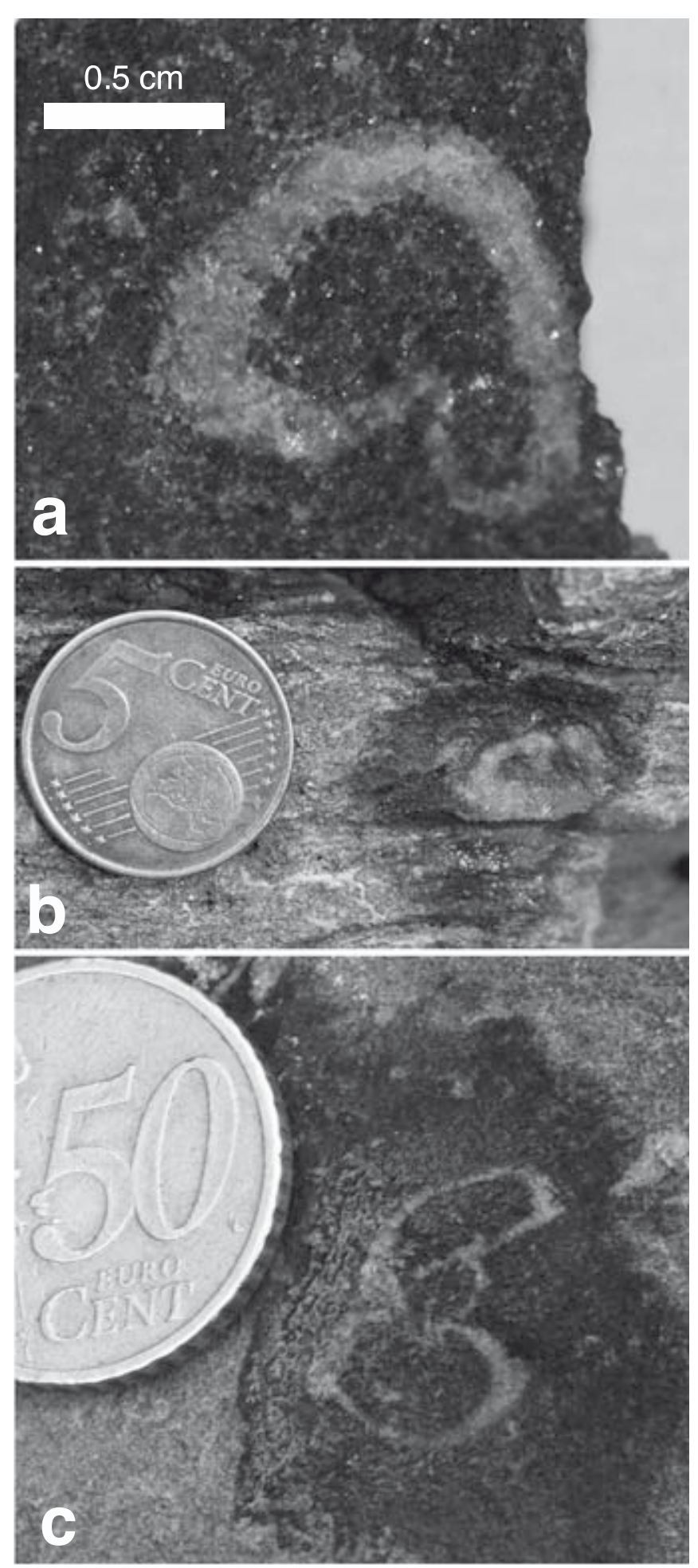

Figure 7. a-b) Sections of possible brachiopods. c) Section of a spiral organism completely filled up with sediment. It is interpreted as a section of a gastropod.

Within this temporal window, the chronological range of the other identifiable taxa can help to further circumscribe the age of the rocks studied. The age range of the rugose coral family Phillipsastreidae is EmsianFamennian (age data from Paleobiology Database: http://paleobiodb.org/\#/), with the genus Peneckiella becoming Lochkovian-Frasnian (Early-Middle Devonian) (age data from Paleobiology Database: http://paleobiodb. org/\#/).

Regarding the cephalopods, they are possible members of the ancestral ammonoid order Agoniatitida (probably the family Mimosphinctidae) or nautiloids. Regardless, their taxonomic attribution of the morphological traits observed in one of the preserved specimens (Fig. 6a) are significant to make a chronological inference. A continuous closing of the umbilical window and an increase in coil tightening in primitive ammonoids are well documented during the Early-Middle Devonian (Klug, 2001; Korn \& Klug, 2003; Klug \& Korn, 2004; Kröger, 2005; Leonova, 2009; De Baets et al., 2012). The enclosed umbilical windows occur in at least three independent ammonoid suborders (De Baets et al., 2012). Nonetheless, stratophenetic and phylogenetic analyses show that all these ammonoids with small-enclosed umbilical windows disappeared by the latest Emsian (Korn \& Klug, 2003; Kröger, 2005; De Baets et al., 2012). There are a few references of Eifelian ammonoids with open umbilicus, although De Baets et al. (2012) have challenged these claims.

In the case of nautiloids, they show a morphological macroevolutionary trend of coiling comparable to that of the ammonoids, although with some differences (Dzik \& Korn, 1992; Kröger, 2005). According to Kröger (2005), first Ordovician nautiloids show tightly coiled shells. Then, a radiation event of forms with an open umbilicus, loose coiling or uncoiled last whorl took place in the Early Devonian. The morphological trend culminated with strongly coiled shells again in the Middle-Late Devonian and onwards (Kröger, 2005).

Consequently, although the coiled cephalopods of the fossil assemblages studied could be identified either as primitive ammonoids or nautiloids, the age range of the planispiral advolute taxa presenting an enclosed open umbilicus and a detached last whorl is limited to the Emsian (Fig. 12). In short, the stratigraphical distribution of the taxa identified from the NFC marbles and calcsilicate schist of the upper unit of the Veleta nappe in the Águilas tectonic arc yields an age older than the one proposed by Lafuste \& Pavillon (1976), i.e., the Eifelian.

Based on all the existing biochronological data together, rocks assigned to the same structural metamorphic complex have been dated as Late Neoproterozoic in the Sierra de Baza (central part of the Betic Cordillera), as Early Devonian in the Águilas tectonic arc (eastern of the Betic Cordillera) and Cretaceous in the Sierra de los Filabres (central part of the Betic Cordillera). This wide age range for the same tectonic unit strongly suggests that the stratigraphy and the structural arrangement of the NFC are probably more complex than accepted hitherto (e.g., Gómez-Pugnaire \& Franz, 1988; Martínez-Martínez et al., 2010; Gómez-Pugnaire et al., 2012). 

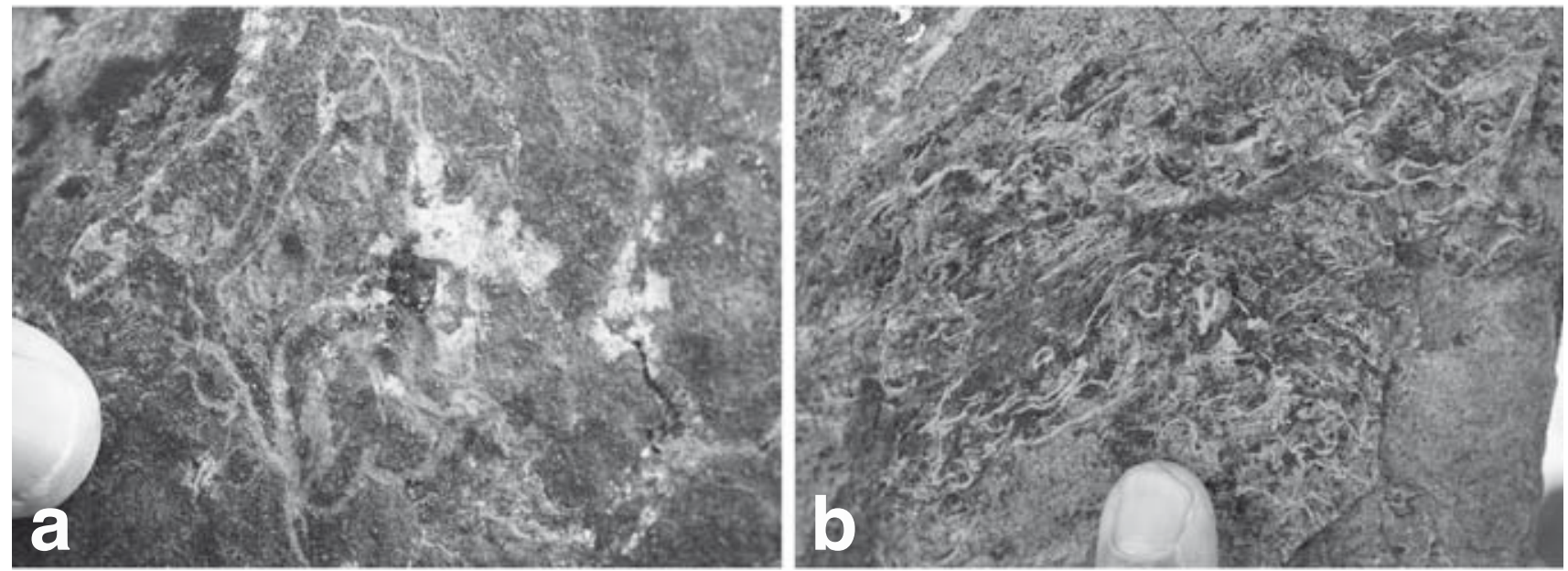

Figure 8. a-b) Laminar, contorted structures resembling calcareous algae. These laminar structures follow neither fractures nor folded calcite veins. They are, therefore, interpreted as organic in origin. Nonetheless, the inner structure has been completely obliterated due to recrystallization, hampering a confident taxonomic attribution.
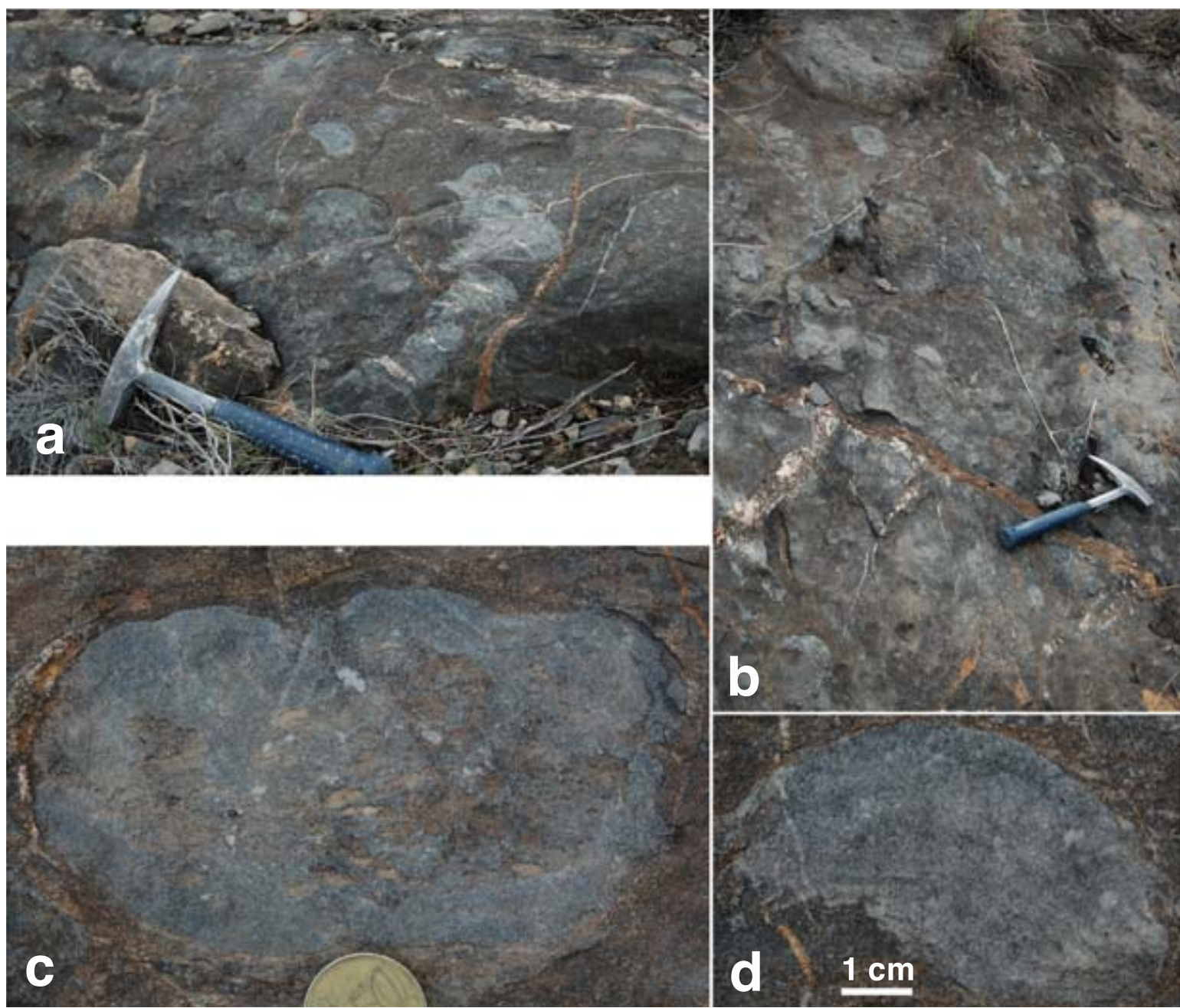

Figure 9. Massive, nodular or irregular structures found in several beds at Barranco de los Asensios section. a-b) Field views of two stratification surfaces showing these massive structures (the lighter grey 'nodules'). c-d) Close-up views of two of these structures. Note a rough internal laminar arrangement. In (d), some vertical structures perpendicular to the outer surface are visible in the upper part of the nodule. 

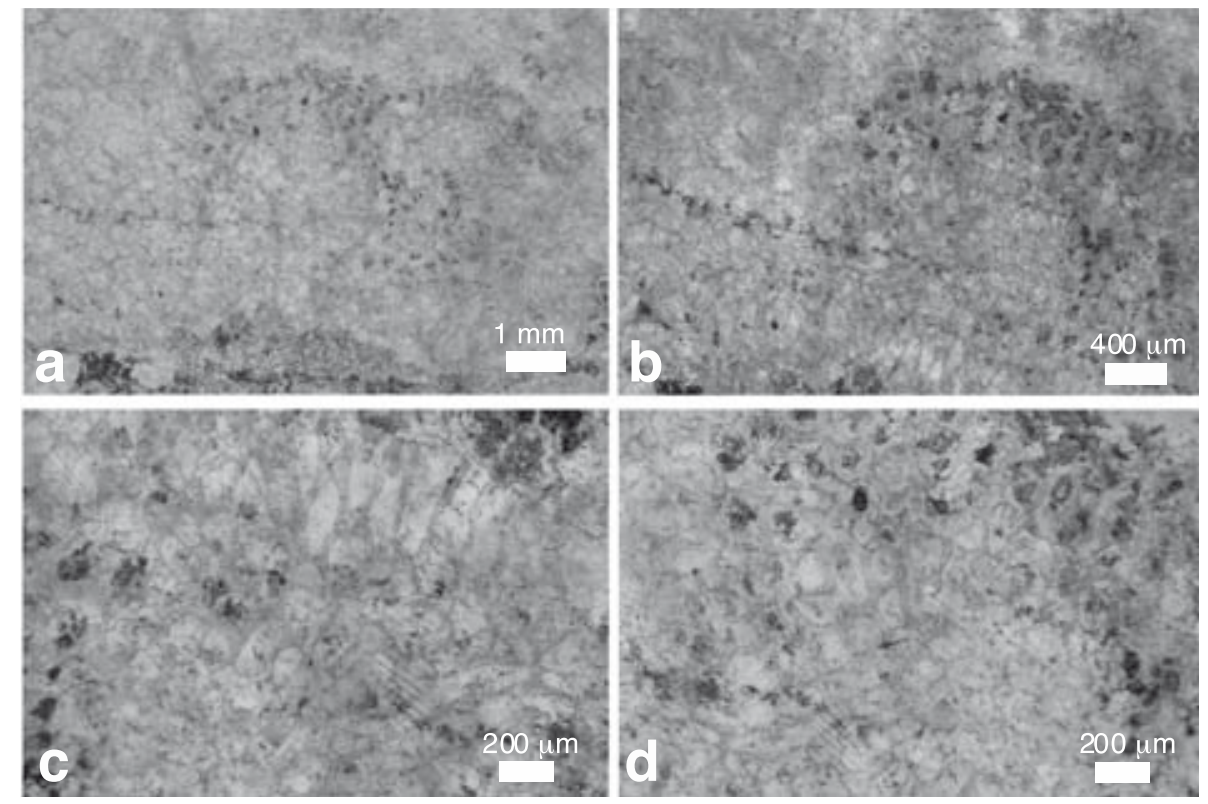

Figure 10. Microphotographs of the massive organisms shown in Figure 9. a) Light transmitted view in thin section. The inner structure has been lost due to pervasive recrystallization. b-d) Detailed views of the same portion of the thin section as in (a), but using a piece of white paper as a light diffuser. Here, 'ghosts' (relicts) of the internal original anatomical features have been preserved. They are tubular elements (b-c) separated by a thick walls that show circular-ovoid outlines in transversal sections (d). These characters resemble anatomical features present in chaetetids or bryozoans.
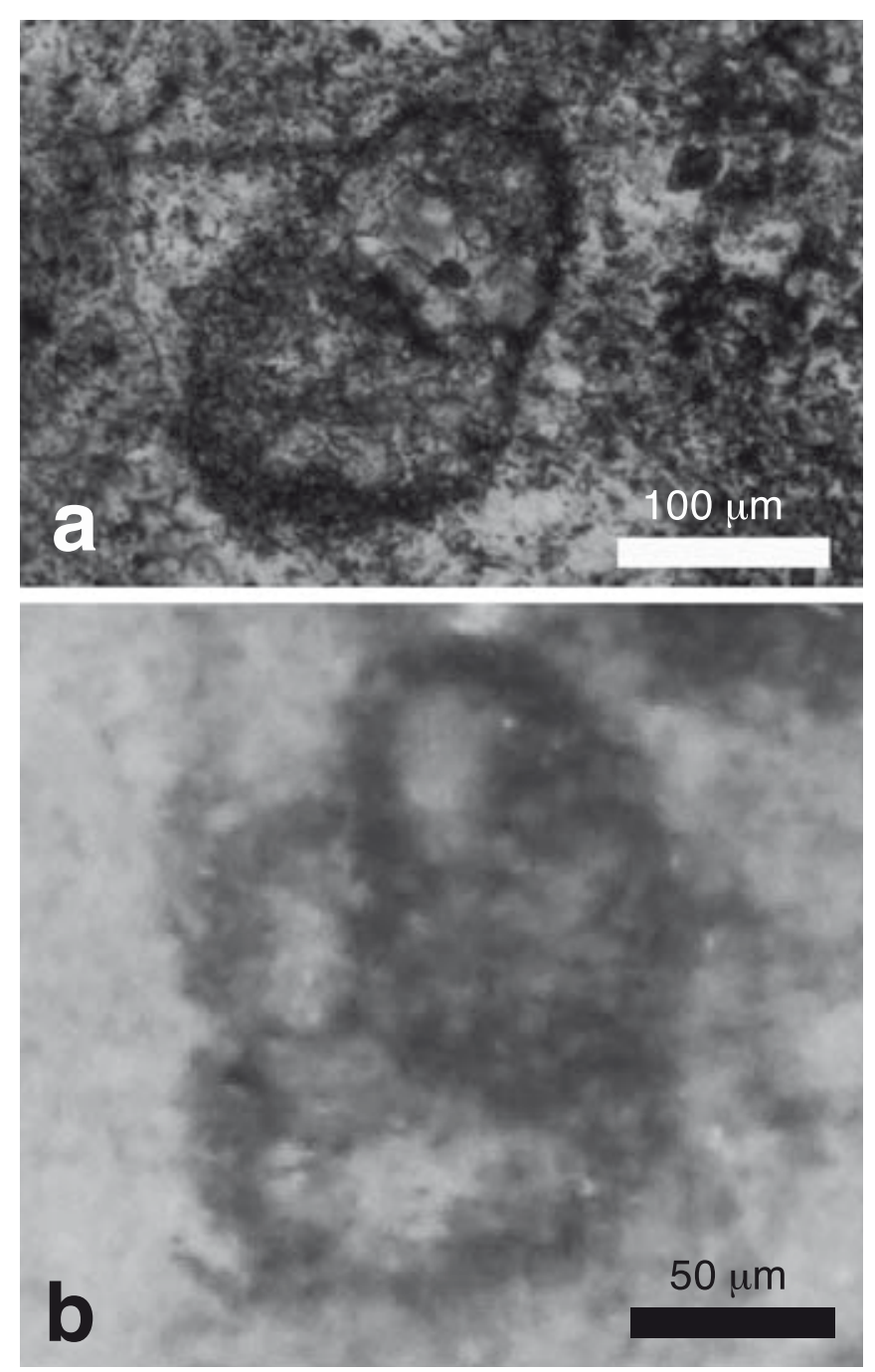

Figure 11. a-b) Ovoid (a) and spiral (b) sections of possible agglutinated benthic foraminifers.

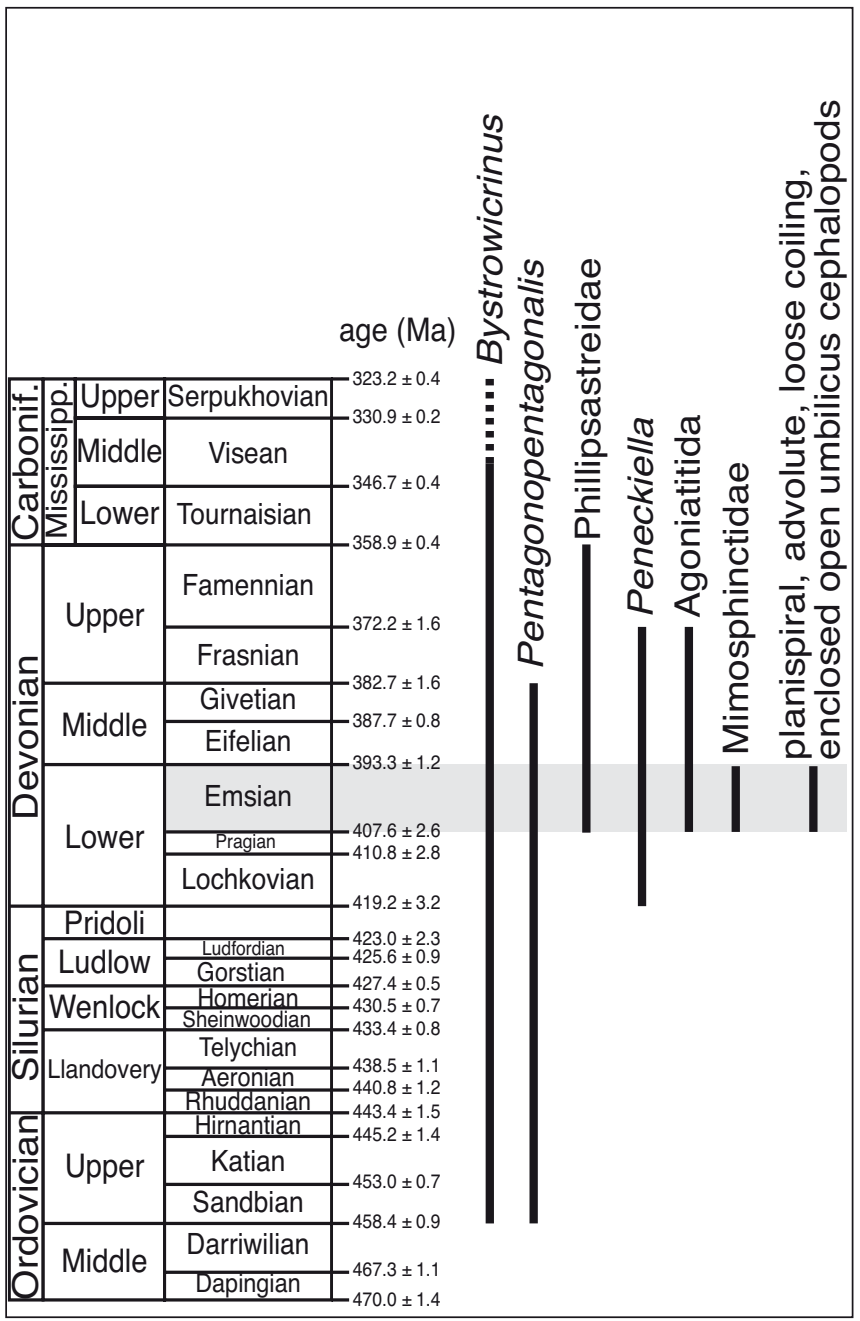

Figure 12. Stratigraphic range of the reliably identified organisms showing that the fossil assemblage can be restricted to the Emsian, latest Early Devonian. 
This, in turn, complicates the proposal of a thorough palaeogeographic context in which the NFC was originally deposited. It is far beyond the scope of this paper to discuss palaeogeographic models proposed for the NFC, but our data nonetheless allow reasonable inferences to be drawn on this issue. Based on the biochronological results, comparisons with coeval rocks of other areas can be performed to provide further clues on the palaeogeographic significance of the study materials.

Taphonomic analysis of the fossil assemblages studied suggests that the metasediments of the Veleta nappe of the NFC in the Águilas tectonic arc were formed most likely in a middle-outer carbonate platform with mass flow deposits, probably due to storm events (Laborda-López \& Aguirre, 2013; Laborda-López et al., 2015). At present, it is well established that the NFC constituted part of the Iberian Massif, which represented the basement of the south Iberian palaeomargin (Gómez-Pugnaire et al., 2004, 2012; Booth-Rea et al., 2007; Behr \& Platt, 2013). According to chemical composition and age of emplacement of late Variscan magmatic rocks in the NFC, Gómez-Pugnaire et al. (2012, fig. 11) proposed that the original sediments forming this tectonic complex were palaeogeographically at the S-SE end of the Iberian Massif and in connection with the Central Iberian (eastern Iberian Massif) and WestAsturo-Leonian (north-western Iberian Massif) Zones. Therefore, the rocks studied would represent shelf deposits associated with the southern Iberian palaeomargin.

\section{CONCLUSIONS}

Marine macrofossils of metamorphic rocks, marbles, and calc-silicate schists, from the so-called Águilas tectonic arc (eastern Betic Cordillera, SE Spain), belonging to the Veleta nappe of the Nevado-Filábride Complex (Internal Zones of the Betic Cordillera), are locally common. Lafuste \& Pavillon (1976) were the first to highlight the presence of these fossils. In the present paper, the original sites studied by these authors, as well as new ones, have been analysed. Three composite sections, distributed between Pilar de Jaravía (Pulpí, Almería) to Ramonete (Lorca, Murcia), have been studied.

The study sections belong to the upper unit of the Veleta (= Lomo de Bas) nappe, which can be divided into three members: a) the lower member is made up of fine-grained metasiliciclastics; b) the middle member, containing the fossils studied, consists of marbles and calc-silicate schist intercalated in phyllites, schists, and quartzites; and c) the upper member is also constituted of fine-grained metasiliciclastics.

Fossil assemblages are dominated by crinoids, which occur as both disarticulated and partially articulated elements. Two columnal parataxa have been identified,
Bystrowicrinus (col.) sp. and Pentagonopentagonalis (col.) sp., as well as stalks and calyxes of possible camerate and/ or cladid crinoids. Other identifiable taxa are sections of cephalopods attributable to primitive ammonoids of the order Agoniatitida and nautiloids. One of these specimens shows features by which it can be confidently identified as a member of the family Mimosphinctidae. In lesser abundance, rugose corals from the family Phillipsastreidae, possibly belonging to the genus Peneckiella, sections of trilobites, gastropods, and brachiopods are also present.

Other enigmatic fossils have been also found. Intense deformation and pervasive recrystallization have affected these fossils and their identification is problematic. Some examples are possible sections of agglutinated benthic foraminifers. Additionally, laminar structures resembling calcareous algae are common. Finally, massive structures potentially assignable to chaetetid sponges or bryozoans are also present.

Fossil assemblages narrow the biochronological age of the carbonate rocks of the upper unit of the Veleta nappe in the Águilas tectonic arc to the Emsian, i.e; late Early Devonian.

\section{ACKNOWLEDGEMENTS}

We appreciate the review made by Juan Carlos GutiérrezMarcos; his comments and suggestions have improved the original version of the manuscript. A Research Grant provided by Sociedad Española de Paleontología has funded one of the authors (CLL). This paper has been partially supported by the Research Project CGL201347236-P of the Ministerio de Ciencia e Innovación of Spain, and the Research Group RNM-190 of the Junta de Andalucía.

\section{REFERENCES}

Aerden, D. \& Sayad, M. 2008. From Adria- to Africa-driven orogenesis: Evidence from porphyroblasts in the Betic Cordillera, Spain. Journal of Structural Geology, 30, 1272-1287.

Álvarez, F. 1987. La Tectónica de la Zona Bética en la Región de Águilas. Tesis Doctoral, Universidad de Salamanca.

Álvarez, F. \& Aldaya, F. 1985. Las unidades de la Zona Bética en la región de Águilas-Mazarrón (Prov. de Murcia). Estudios Geológicos, 41, 139-146.

Azañón, J.M., Galindo-Zaldívar, J., García-Dueñas, V. \& Jabaloy, A. 2002. Alpine tectonics II: Betic Cordillera and Balearic Islands. In: The Geology of Spain (eds. Gibbons, W. \& Moreno, T.). The Geological Society, London, 401-416. 
Behr, W.M. \& Platt, J.P. 2013. Rheological evolution of a Mediterranean subduction complex. Journal of Structural Geology, 54, 136-155.

Bernard, S., Benzerara, K., Beyssac, O., Menguy, N., Guyot, F., Brown, Jr., G.E. \& Goffé, B. 2007. Exceptional preservation of fossil plant spores in high-pressure metamorphic rocks. Earth and Planetary Science Letters, 262, 257-272.

Bernard, S., Benzerara, K., Beyssac, O. \& Brown, Jr., G.E. 2010. Multiscale characterization of pyritized plant tissues in blueschist facies metamorphic rocks. Geochimica et Cosmochimica Acta, 74, 5054-5068.

Booth-Rea, G., Ranero, C.R., Martínez-Martínez, J.M. \& Grevemeyer, I. 2007. Crustal types and Tertiary tectonic evolution of the Alborán Sea, western Mediterranean. Geochemistry, Geophysics, Geosystems, 8, 1-25.

Bucher, W.H. 1953. Fossils in metamorphic rocks: A review. Geological Society of America Bulletin, 64, 275-300.

Cavargna-Sani, M., Epard, J.-L. \& Masson, H. 2010. Découverte de fossiles dans la nappe de l'Adula, nouvelles données stratigraphiques et conséquences tectoniques (Alpes centrales). Bulletin de la Société vaudoise des Sciences naturelles, 92, 77-84.

Danto, J. 1973. Corps mineralisés plombifères familiers, secants et stratiformes dans les formations métamorphiques de la region d'Aguilas-Almagrera (Murcie, Espagne). $\mathrm{PhD}$ Thesis, Laboratoire de Géologie appliquées, Paris.

Daubrée, M. 1876. Expériences sur la schistosité des roches et sur les déformations des fossiles, corrélatives de ce phénomène: conséquences géologiques de ces expériences. Bulletin des services de la carte géologique de la France, Série 3, 4, 529-552.

De Baets, K., Klug, C. \& Monnet, C. 2013. Intraspecific variability through ontogeny in early ammonoids. Paleobiology, 39, 75-94.

De Baets, K., Klug, C., Korn, D. \& Landman, N.H. 2012. Early evolutionary trends in ammonoid embryonic development. Evolution, 66, 1788-1806.

De Wever, P., Duée, C. \& El Kadiri, K. 1985. Les séries stratigraphiques des klippes de Chrafate (Rif Sepentrional, Maroc) témoins d'une marge continentale subsidente au cours du Jurassique-Crétacé. Bulletin de la Societé Géologique de France, 1, 363-379.

Delgado, F. 1977. Primary textures in dolostones and recrystallized limestones; a technique for their microscopic study. Journal of Sedimentary Research, 47, 1339-1341.

Donovan, S.K. 2012. Notes on Lower Devonian crinoids in the collections of the British Geological Survey, Keyworth. Proceedings of the Yorkshire Geological Society, 59, 115-120.

Donovan, S.K. 2013. Giant crinoid stems from the Lower Carboniferous (Mississippian) of Clitheroe, Lancashire, UK. Proceedings of the Yorkshire Geological Society, 59, 211-218.

Donovan, S.K. \& Harper, D.A.T. 1992. The pelmatozoan fauna of the High Mains Formation (Ordovician: Hirnantian) of the Craighead Inlier, Strathclyde. Transactions of the Royal Society of Edinburgh, 83, 669-677
Donovan, S.K. \& Wright, A.D. 1995. Pelmatozoan (crinoid?) columnals from the Hirnantian (Ordovician, Ashgill) of Keisley, Cumbria, UK. Proceedings of the Yorkshire Geological Society, 50, 229-238.

Dzik, J. \& Korn, D. 1992. Devonian ancestor of Nautilus. Paläontolgische Zeitschrift, 66, 81-98.

Egeler, C.G. \& Simon, O.J. 1969. Orogenic evolution of the Betic Zone (Betic Cordilleras, Spain) with emphasis on the nappe structures. Geologie en Mijnbouw, 48, 296-305.

Flügel, E. 2002. Microfacies of Carbonate Rocks. Analysis, Interpretation and Application. Springer, Berlin.

Galvez, M.E., Beyssac, O., Benzerara, K., Bernard, S., Menguy, N., Cox, S.C., Martinez, I., Johnston, M.R. \& Brown G.E., Jr. 2012. Morphological preservation of carbonaceous plant fossils in blueschist metamorphic rocks from New Zealand. Geobiology, 10, 118-129.

Gomez-Pugnaire, M.T. \& Franz, G. 1988. Metamorphic evolution of the Palaeozoic series of the Betic Cordilleras (Nevado-Filabride complex, SE Spain) and its relationship with the alpine orogeny. Geologische Rundschau, 77, 619-640.

Gómez-Pugnaire, M.T., Ulmer P. \& Sánchez-Vizcaíno, V. 2000. Petrogenesis of the mafic igneous rocks of the Betic Cordilleras: A field, petrological and geochemical study. Contribution to Mineralogy and Petrology, 139, 436-457.

Gómez-Pugnaire, M.T., Galindo-Zaldívar, J., Rubatto, D., González-Lodeiro, F., Sánchez-Vizcaíno, V. \& Jabaloy, A. 2004. A reinterpretation of the Nevado-Filábride and Alpujárride Complex (Betic Cordillera): field, petrography and $\mathrm{U}-\mathrm{Pb}$ ages from orthogneisses western Sierra Nevada, S Spain. Schweizerische Mineralogische und Petrographische Mitteilungen, 84, 303-322.

Gómez-Pugnaire, M.T., Chacón, J., Mitrofanov, F. \& Timofeev, V. 1982. First report on pre-Cambrian rocks in the graphite-bearing series of the Nevado-Filábride Complex (Betic Cordilleras, Spain). Neues Jahrbuch für Geologie und Palaeontologie Monatshefte, 3, 176-180.

Gómez-Pugnaire, M.T., Rubatto, D., Fernández-Soler, J.M., Jabaloy, A., Sánchez-Vizcaíno, V., González-Lodeiro, F., Galindo-Zaldívar, J. \& Padrón-Navarta, J.A. 2012. Late Variscan magmatism in the Nevado-Filábride Complex: $\mathrm{U}-\mathrm{Pb}$ geochronologic evidence for the pre-Mesozoic nature of the deepest Betic complex (SE Spain). Lithos, 146-147, 93-111.

Hanel, M., Montenari, M. \& Kalt, A. 1999. Determining sedimentation age of high-grade metamorphic gneisses by their palynological record: a case study in the northern Schwarzwald (Variscan Belt, Germany). International Journal of Earth Sciences, 88, 49-59.

Hill, M.L. 1985. Remarkable fossil locality: Crinoid stems from migmatite of the Coast plutonic complex, British Columbia. Geology, 13, 825-826.

Javaux, E.J. \& Benzerara, K. 2009. General palaeontology (taphonomy and fossilization). Microfossils. Comptes Rendus Palevol, 8, 605-615.

Korn, D. \& Klug, C. 2003. Morphological pathways in the evolution of Early and Middle Devonian ammonoids. Paleobiology, 29, 329-348. 
Klug, C. 2001. Early Emsian ammonoids from the eastern AntiAtlas (Morocco) and their succession. Paläontolgische Zeitschrift, 74, 479-515.

Klug, C. \& Korn, D. 2004. The origin of ammonoid locomotion. Acta Palaeontologica Polonica, 49, 235-242.

Kröger, B. 2005. Adaptive evolution in Paleozoic coiled cephalopods. Paleobiology, 31, 253-268.

Kurilenko, A.V. \& Kulkov, N.P. 2008. A proposed crinoid zonation of the Devonian deposits of eastern Transbaikal. Bulletin of Geosciences, 83, 461-472.

Laborda-López, C. \& Aguirre, J. 2013. Exceptional fossilization in marbles. Journal of Taphonomy, 11, 49-50.

Laborda-López, C., Aguirre, J. \& Donovan, S.K. 2013. Asociaciones de macrofósiles en rocas metamórficas del Complejo Nevado-Filábride (Zonas Internas de la Cordillera Bética) en Águilas, Murcia (SE España). Tafonomía y biocronoestratigrafía. XXIX Jornadas de Paleontología, Córdoba, Libro de Resúmenes, p. 83-84.

Laborda-López C., Aguirre, J. \& Donovan, S.K. 2014. Exceptional preservation in marbles of the NevadoFilábride Complex (Betic Cordillera, SE Spain). 7th International Meeting on Taphonomy and Fossilization, TAPHOS 2014, Ferrara (Italy), Abstract Book, p. 49-50.

Laborda-López, C., Aguirre, J. \& Donovan, S.K. 2015. Surviving metamorphism: Taphonomy of fossil assemblages in marbles and calc-silicate schists. Palaios, 30, 668-679.

Lafuste, J. \& Pavillon, M.J. 1976. Mise en evidence d'Eifélien date au sein des terrains métamorphiques des zones internes des Cordillères bétiques. Intérêt de ce nouveau repère stratigraphique. Comptes Rendus de l'Academie des Sciences de Paris, 283, 1015-1018.

Leonova, T.B. 2009. Ecological structure of Paleozoic ammonoids. Paleontological Journal, 43, 514-518.

Martín-Algarra, A. \& Estévez, A. 1984. La brèche de la Nava: dépôt continental sychrone de la structuration pendant le Miocène inférieur des zones internes de l'ouest des Cordillères bétique. Comptes Rendus de l'Académie des Sciences de Paris, 299, 463-466.

Martínez-Martínez, J.M., Soto, J.I. \& Balanyá, J.C. 2002. Orthogonal folding of extensional detachments: structure and origin of the Sierra Nevada elongated dome (Betics, SE Spain). Tectonics, 21, doi:10.1029/2001TC001283.

Martínez-Martínez, J.M., Torres-Ruiz, J., Pesquera, A. \& Gil-Crespo, P.P. 2010. Geological relationships and U-Pb zircon and ${ }^{40} \mathrm{Ar} /{ }^{39} \mathrm{Ar}$ tourmaline geochronology of gneisses and tourmalinites from the Nevado-Filabride complex (western Sierra Nevada, Spain): tectonic implications. Lithos, 119, 238-250.

Moorbath, S. 2005. Dating earliest life. Nature, 434, 155.

Platt, J.P., Behr, W.M., Johanesen, K.A. \& Williams, J., 2013. The Betic-Rif arc and its orogenic hinterland: A review.
Annual Reviews of Earth and Planetary Sciences, 41, 14.1-14.45.

Pflug, H.D. \& Reitz, E. 1987. Palynology in metamorphic rocks: indication of early plants: Naturwissenschaften, 74, 386-387.

Puga, E. 1977. Sur l'existence dans le complexe de la Sierra Nevada (Cordillère bétique, Espagne du Sud) d'éclogites et sur leur origine probable á partir d'une croûte océanique mésozoïque. Comptes Rendus de l'Académie des Sciences de Paris, Série II, 285, 1379-1382.

Puga, E. 1990. The Betic ophiolitic association (southeastern Spain). Ofioliti, 15, 97-117.

Sánchez-Vizcaíno, V., Rubatto, D., Gómez-Pugnaire, M.T., Tommsdorff, V. \& Müntener, O. 2001. Middle Miocene high-pressure metamorphism and fast exhumation of Nevado-Filábride Complex, SE Spain. Terra Nova, 13, 327-332.

Schiffbauer, J.D., Wallace, A.F., Hunter, J.L., Kowalewski, M., Bodnar, D.J. \& Xiao, S. 2012. Thermally-induced structural and chemical alteration of organic-walled microfossils: an experimental approach to understanding fossil preservation in metasediments. Geobiology, 10, 402-423.

Sharpe, D. 1847. On slaty cleavage. Quarterly Journal of the Geological Society, 3, 74-105.

Sharpe, D. 1849. On slaty cleavage (second communication). Quarterly Journal of the Geological Society, 5, 111-129.

Tendero, J.A., Martin-Algarra, A., Puga, E. \& Diaz de Federico, A. 1993. Lithostratigraphy of the metasediments of the Nevado-Filabride ophiolitic association (SE Spain) and discovery of ankerite spots resembling Cretaceous planktonic foraminifera: palaeogeographic consequences. Comptes rendus de l'Académie des sciences. Série 2, 316, 1115-1122.

Termier, H. \& Termier, G. 1970. Sur une roche crystalline renfermant une écaille d'Echinoderme (Massif du Tichka, Haut Atlas occidentale, Maroc). Comptes Rendus Hebdomadaires des Séances de l'Académie des Sciences, Série D, 270, 1092-1095.

Wildi, W. 1983. La chaîne tello-rifaine (Algérie, Maroc, Tunisie): structure, stratigraphie et évolution du Trias au Miocène. Revue de Géologie Dynamique et de Géographie Physique, 24, 201-297.

Yeltysheva, R.S. 1955. Class Crinoidea, sea lilies, crinoid stems. In: Polevoi Atlas Ordovikskoi i Siluriskoi Fauny Sibirskoi Platformy. Vses. Nauchno-lssled. (ed. Nikiforova, O.I.), Geol. Inst. [VSEGPI], Trudy, 40 7, fig. 7-8, 23, 37, 54 (in Russian).

Yeltysheva, R.S. \& Stukalina, G.A. 1963. Stems of Ordovician and Lower Silurian crinoids of Central Taymyr, Novaya Zemlya and Vaygach. Paleontological and Bioestratigraphic series, 2, 23-62 (in Russian). 
